閒水利.工程已於三月㓩開始動工, 預定六月間完竣, 邆

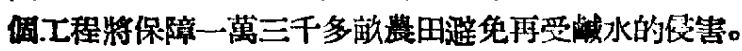

(解放日赫)

\section{7 束北立次整成拖拉機}

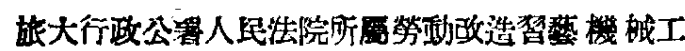

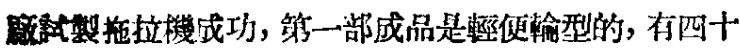

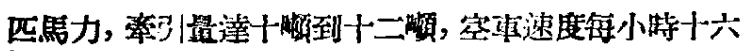
公里, 拖十顿特平道每小特十二公里, 上坟五公里。作耕 地訌验，運轉情况是好。

(東北日報)

\section{8 四月三日月全企}

四月三日清量我阈見到笨一次月全食。三時九分

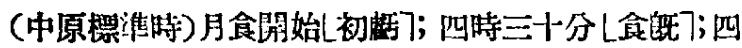

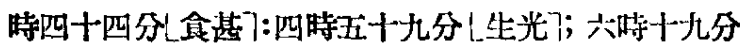
【復国７。因月球已在六時左右下山了，所以我琙東部备 地都來不及看到復圆，但主要的過程都能看到，在酉部 因四、四川等省則可以看完全部月食橙過。(人民日報)

\section{9 地質學者將出墢探測碳座}

在中央人民政府重工棠、燃料、水利三個部湎導下，

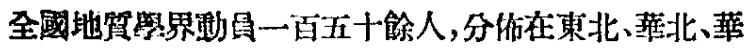

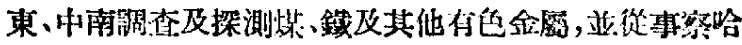
爾的永定河防洪区河北的拒鴚河水力發電等兩大水利 工程的地留工作。

(解放日報)

\section{0 我國新墢現的一種碳産一一蛙石}

一九四九年十一月謝家榮、郭交魁、王承䄍、段承

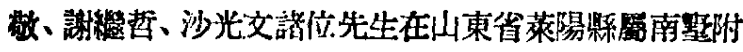

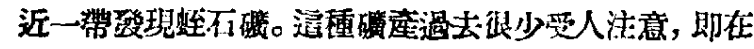

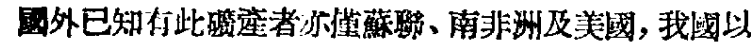
往更少有人注意它。蛀石對建策事業起了革新的作用,

\section{國 外之 部}

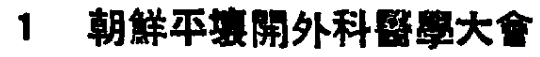

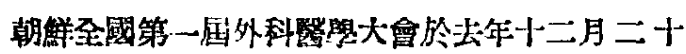

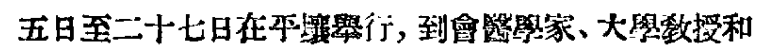
保健事業工作人员共一百五十餘人。在朝鮮的蘇聯䜿學 家阿鲁米諾恩数授及北京酸院外科主任周摆昭称首的

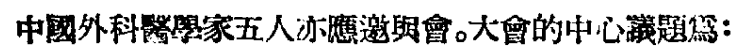

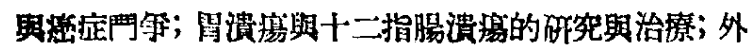
的、骨能炎及其治潦等。

\section{2 人造胃管}

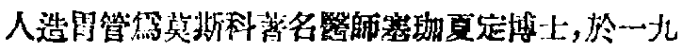
四九年所登明。人造等管就是替病人刢造一悠新的食

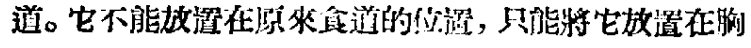

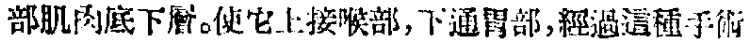
的人住淮食時,人們可以看見食物沿着人造胃管底卜洛
它是一種絕佳的建勧材料, 其防火力甚强，並日蛙石灰

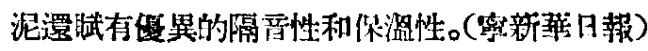

\section{1 亞細亞鎡鐵倣試製磁䚗成功}

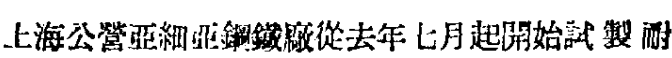

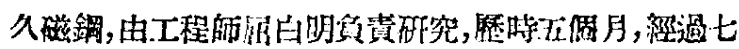

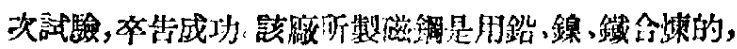

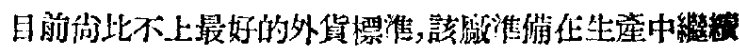
研究, 逐步提高品等。

（㳻大公報）

\section{2 濟南舉行山東全省生座展覽合}

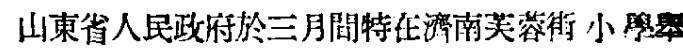

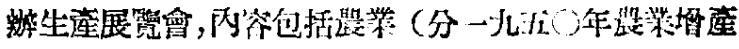

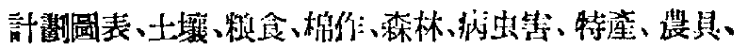

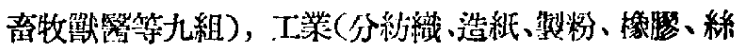

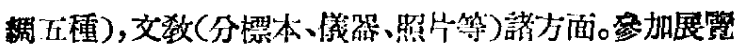

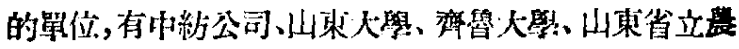

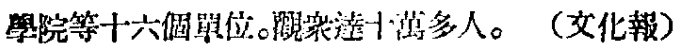

\section{3 中國天文學會在蜜舉行年會}

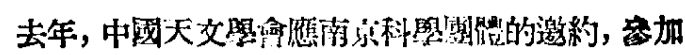

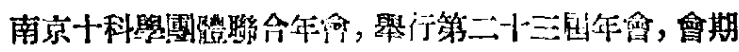
是十二月十日至十一日雨大。第一天上个佂妕央研究院

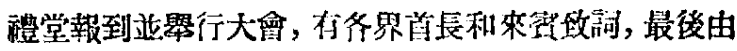

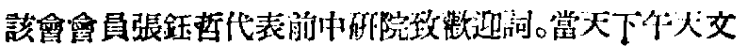

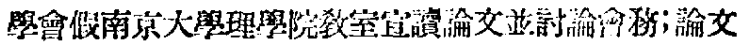

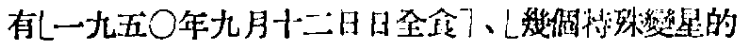

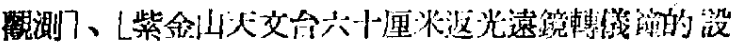

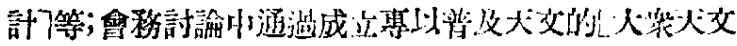

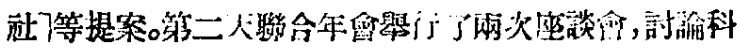

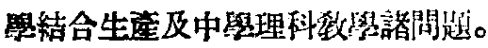

\section{(大寊天文)}

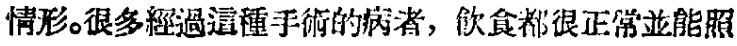
筈工作。

\section{3 電道送書}

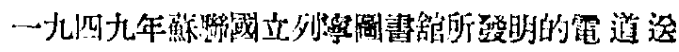

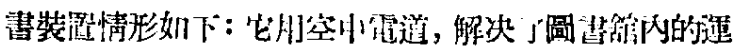

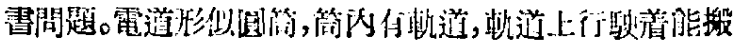

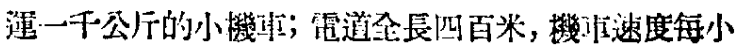
時十无公里。加强连書效率七倍釉。

\section{4 縮影書}

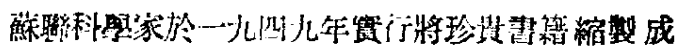

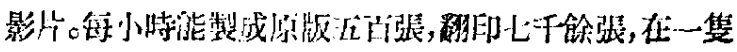

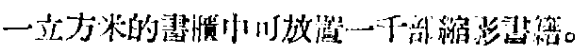

\section{5 口說打字機}


一九目九年蘇聯科學家發明了口說打字機,只須用

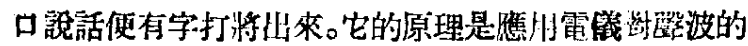

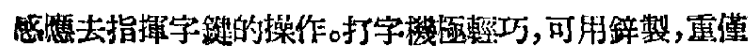
一、二傍。

\section{6 透明铜鐵}

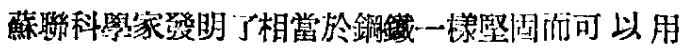
以造房子的透明塑料，可桶之曰透明鋼鐵。

\section{7 喷雨機}

蘇聯最近發明一種噴雨飛機，丽自機喃中噴出，一

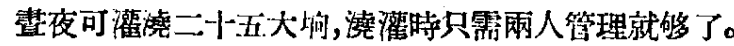

8 瓦斯發動機

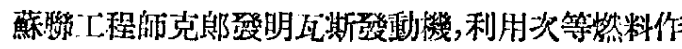

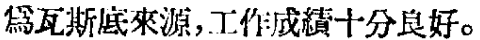

\section{9 蘇聯在機械工程上的新成就}

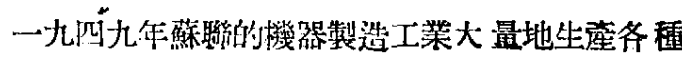

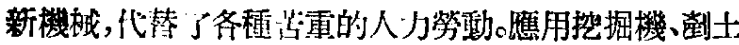
機、開路嘰、均清機，水力機等所作的土方數量比一九四 八年增加了很多。相倍每過幾年，士方工作就可完全機 械化洏不用人力了。

\section{0 多科查也夫農業研究所近聞}

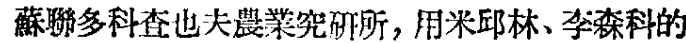
方法在短期內使作物座量增加了三倍，而且一年年更加 增高了，他們還應用米邱林、李森科的方法從事育種工

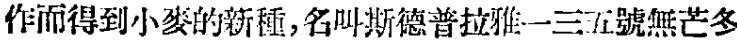

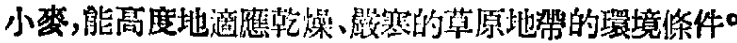

\section{1 破暘風毒素可醫治瘄疾}

莎列賓共和國刺占那地方的高粐㠊疾病家伽西互

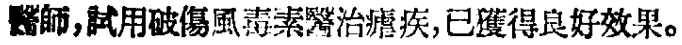

\section{2 南洋槙榔嶼設立漁業研究院}

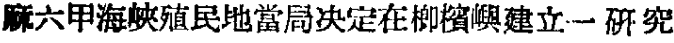
舆部就學院, 以研究淡水奥的㑡恙。

\section{3 日本湯川秀樹獲一九四九年諾 貝黹物理學獎金}

渴川唀樹係日本京都大罢物理學教授，因研究原子 能之論交㨦諾貝爾奨金。

\section{4 蘇聯的兒童鐵道}

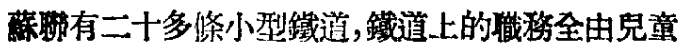

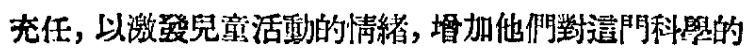
了解。

\section{5 羅馬尼亞建築多珽河黑海間 運河}

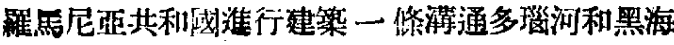

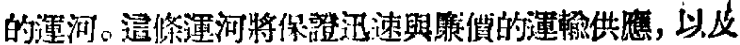
羅馬尼恶南部地通的工菜化及經沙與文化的發展。

\section{6 用嫁接法改進蔬荣的品質}

蘇聯的伷凡申科上正試驗把馬鈴暮和蕃茄嫁 接在

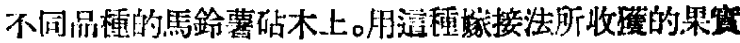

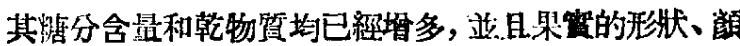
色和渠片的形狀也有政變。

\section{7 中央亞細亞的水槢品程}

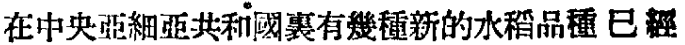
育成。其中包括若干耐塞品種可以提早播種而在七月畏 收难; 還有一個品種僅需七十五天到八十天就能成䓡。

\section{8 蕃茄的無性雜種}

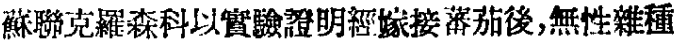

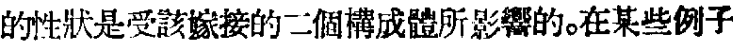
中無性雜種可以增進優良的性狀。

\section{9 多年生小麥}

在蕉聯南部多年生小娄已由集娟農場裁種 了若干

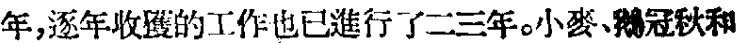
黑麥的雜父工作還在繼續推進中。

\section{0 蘇聯科學院去年招收了五十四 種民族的毒年科學家}

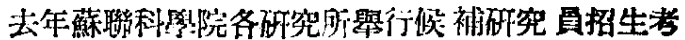
試時，部多共和成、邊區和州的青年聂家都來到了莫斯 科雅身於科學事業,他們代表了五十四種民族。

\section{1 配尼西林在最初原是俄羅斯科 學界的發明}

葉爾莫梅娃呚授程，配尼西林是一八七一年至一八

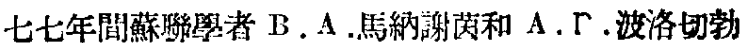
諾夫底發明，當時，他們就公倠了關於利用維微來有效

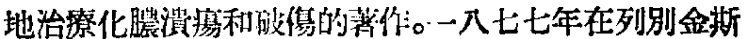

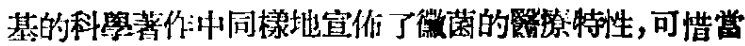
時末能獲得進一步的發展。

\section{2 新式風車}

蕉聯工程師把鹪風車改造後,達到了六十䔽匹馬力 的總動力, 可以把地下幾千心深的煤油, 吸到地面上來, 並且可以轉動發動機。

\section{3 電力汽車}

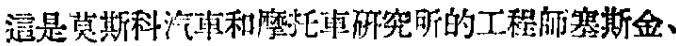
列茹尼格和保依格三人领導下集體設計而製浩出來的。

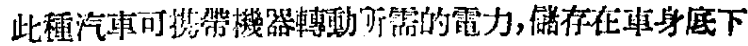
莣電池中, 湆電池的電力一次可走六十五公里, 晚.上可

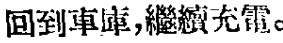

\section{4 自動搬運機}




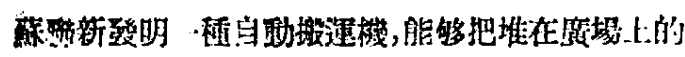

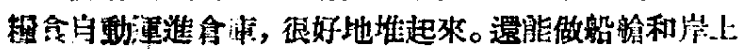

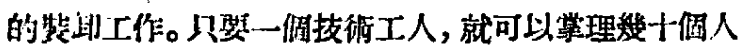
的工作。

\section{5 自動清㛿街道的車}

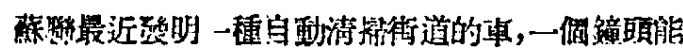

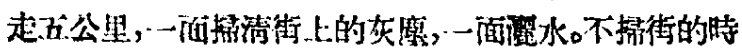
㛺，也可以战入十公厅的貨物。

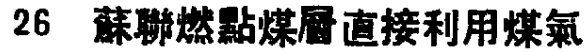

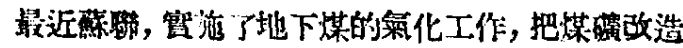

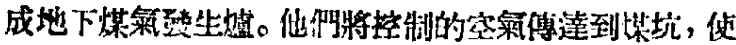

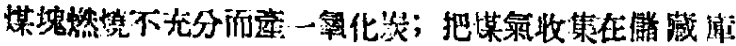

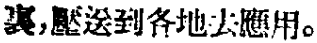

\section{7 蘇聯製鐵軌银機性能冠全球}

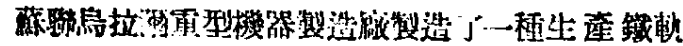

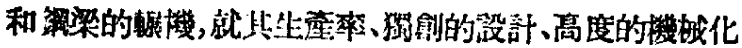

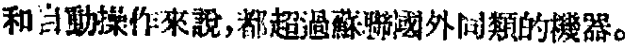

\section{8 憡聯水力透平逨勝美國}

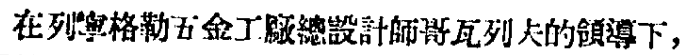

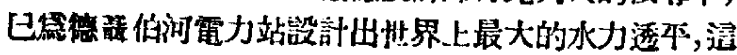

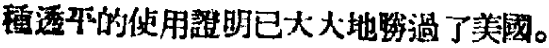

\section{9 体聯新的乾管電㧹法已廣泛地 應用}

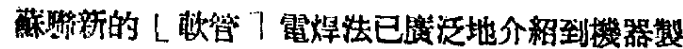

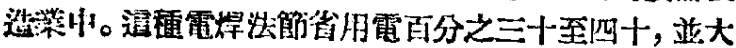

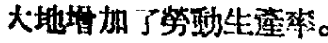

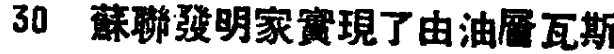 勃察石油的理想}

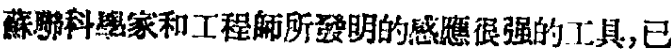

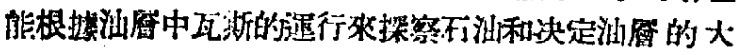
小。

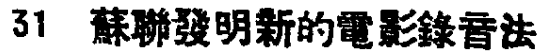

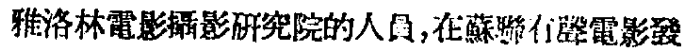
明家達吉爾的领瓷下，發明了新的電影雓晋法。

\section{2 三年前蘇聯隄石雮的調査}

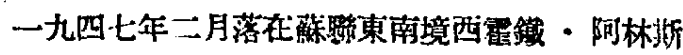

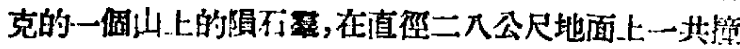

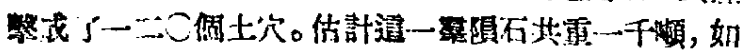

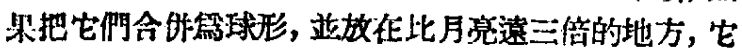
梿好像一顆十五等的小行星。

\section{3 郭沫若電賀約里奥・居里数授 的䑧辰}

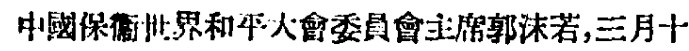

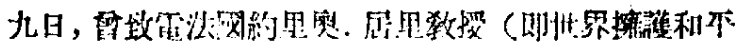

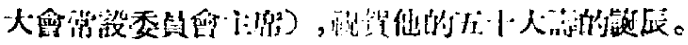

\section{4 吳玉章電賀居里教授的数辰}

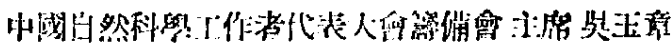

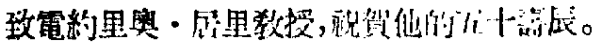

\section{5 萑聯科學院主席国電贺 居里教授}

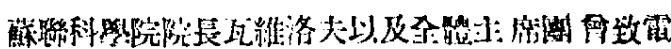

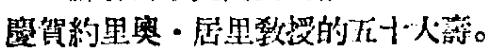

\section{6 一九四八年度蘇聯斯大林獎金 得獎者名單}

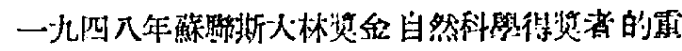
装名單如㐋:

$$
\text { 一等贤: }
$$

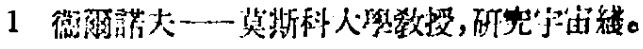

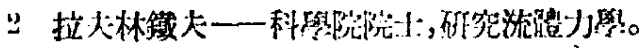

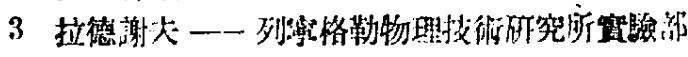

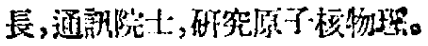

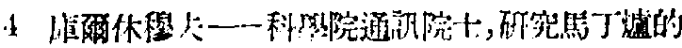
原理，金露接治罗。

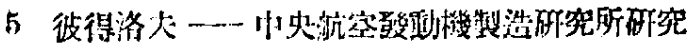

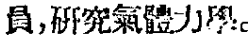

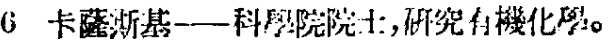

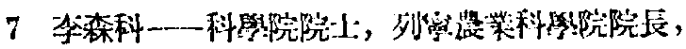
矿究装澲生物學。

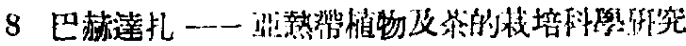
所盒治评分所所長，是一位女性，矿究茶的坐理。

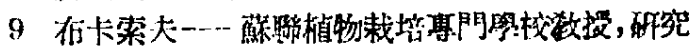

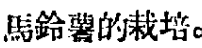

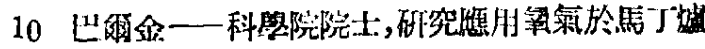
的生兗。

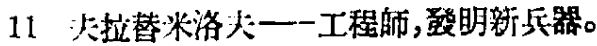

12. 特哥察里大一-工程所, 發明新兵器。

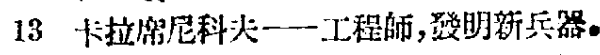

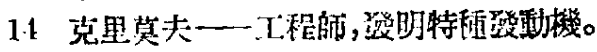

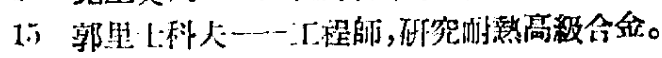

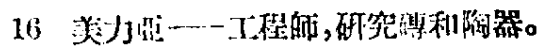

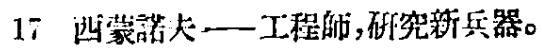

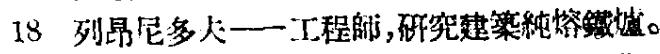

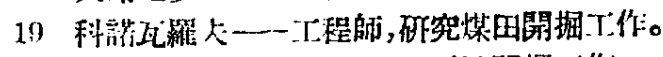

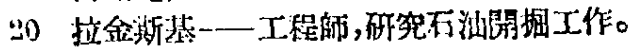

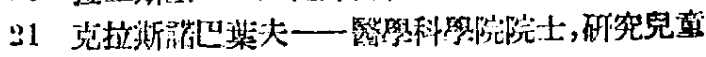

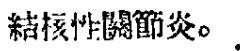
-. 等紧:

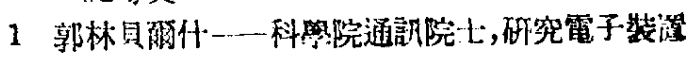
的部算和没部。

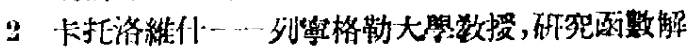
析改隹小數學!。

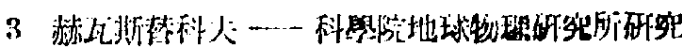


悬，研究航空及大氣光罳。

4 基里洛夫，一列繁格勒工業大照教授，研究蒸 氣洞堬的製浩。

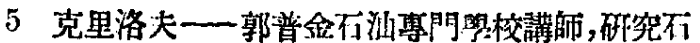
油發堀。

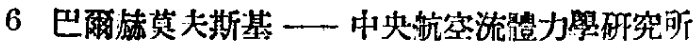
研究員, 研究機栈學。

7 波波夫-D列窗格勒紅軍航空技術研究院数授， 研究彈性理諭。

8 拉赫莫托維一一科照院院士, 呼究波動的理确。

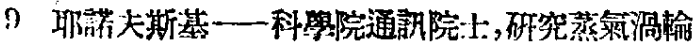
的酎久性與其設計。

10 赛爾郭普洛澌基——蕉聯像膠科學研究听, 研究 人造潒膠。

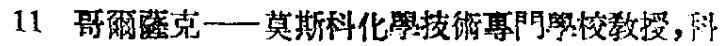
學院有機化學研究所研究員, 研究有媵化罢。

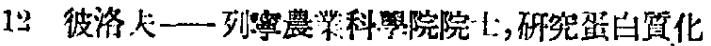
祭。

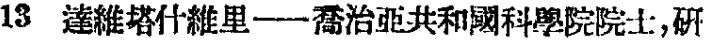
究渞化稀和生物學吏。

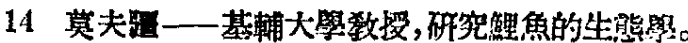

15) 费特洛大一一莫斯科農業科學院研究員，研究士 壤細菌。

10 亞・摩・替莫費耶夫一一莫斯科農業科學院研 究員, 研究牧草。

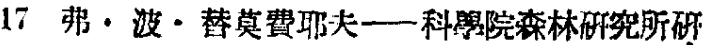
究咸，研究落集忪的生物學。

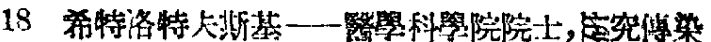
宊。(完)

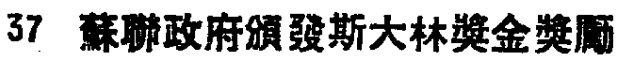 一九四九年卓越的創造和發明}

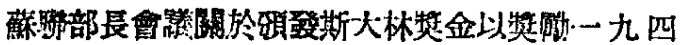
九个卓越的科學蓄作和登明的决䉝，已經發表如下的公 作:

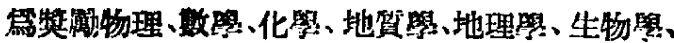

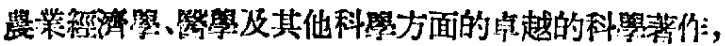

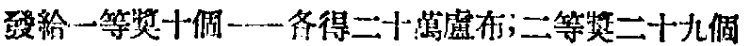

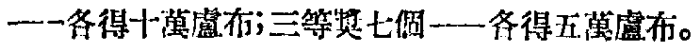

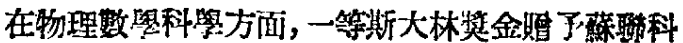

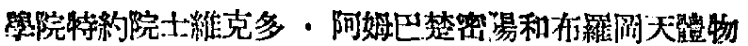

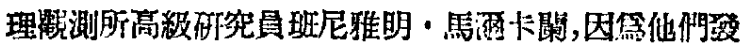

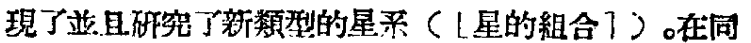
一方面，一等斯大林獎金並已囎予科學院院士格雷高

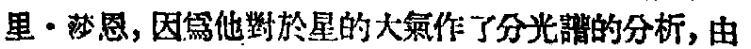
於遙種分析，已發現其中有內容非常奇異的通炭同位原 素。

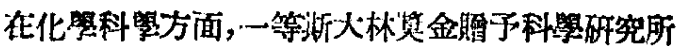

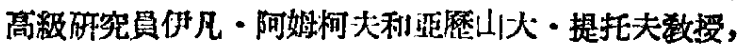

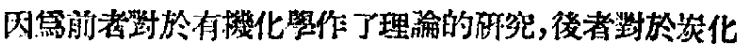

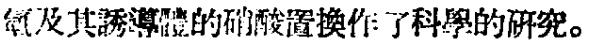

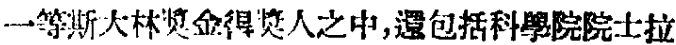

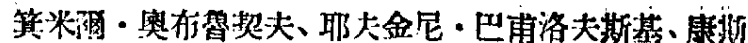
坦丁・斯克里雅本、莫斯科第二紫然研究所数授尼古

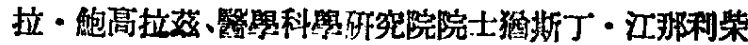
等。

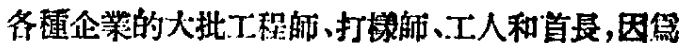

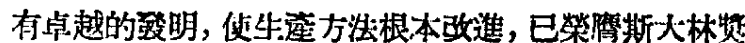
金。例如國立處理棉花機㧴的惠門打様局的工程師們格

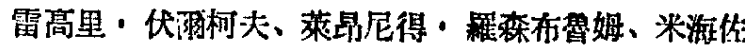

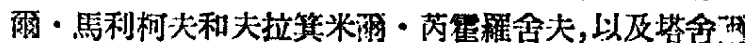

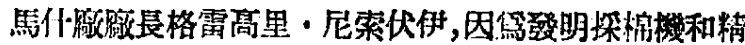

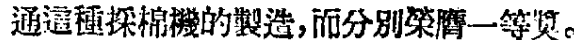

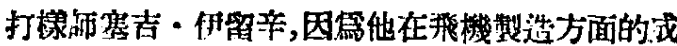

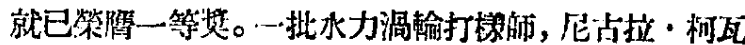

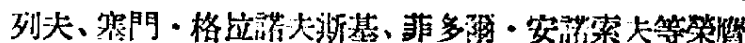

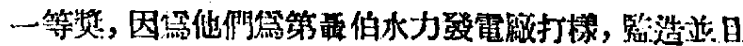
裴好了新的更好的水力渦输, 具有十㵧需二千馮力的功 能。

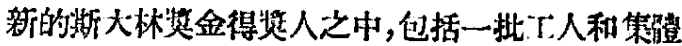

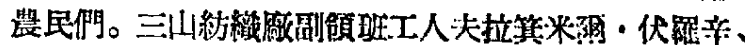

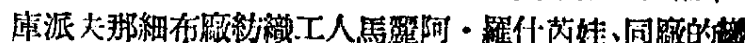

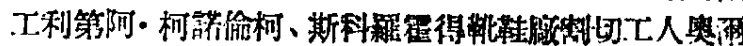

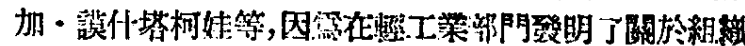

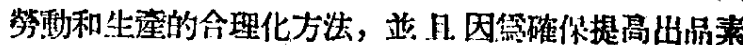

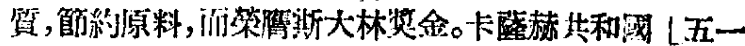

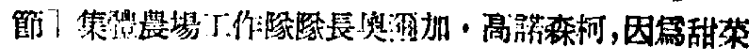
很豐收润榮腐澌大林獎金。

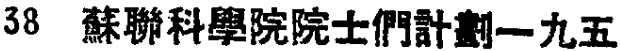 O年度底主要工作}

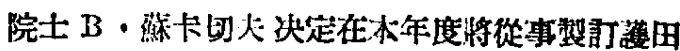

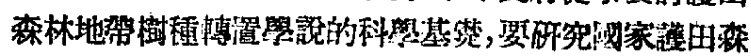

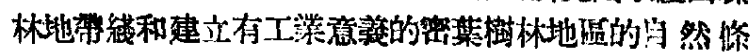

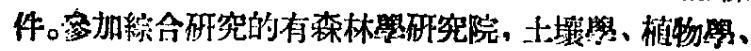

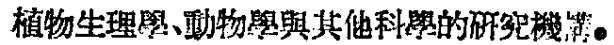

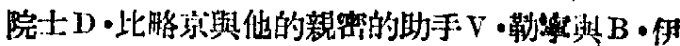

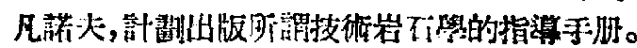

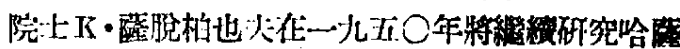

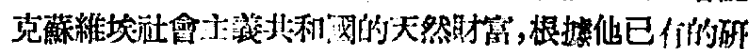

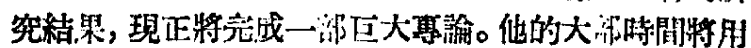

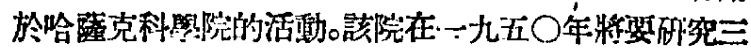
三○偲科學题川。

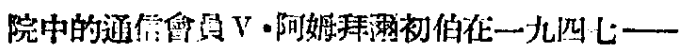

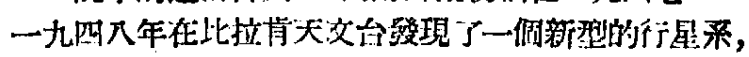
他名此曰星協。本年度他與比拉有天文台的工作雷心， 就在通星協底破究上。

\section{9 國際赛験細胞學研究雑誌第一 期已出版}

國際細胞生物照會 (International Suciety for Cell

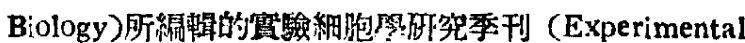
Cell Research)第一期已消版, 由紐約 Academic Press

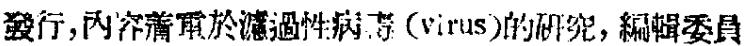

第一期

科學通報
- 55 • 


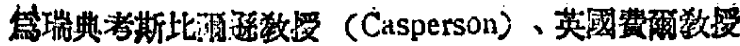
(Fell) 等。

\section{0 巴西科學促進合已成立}

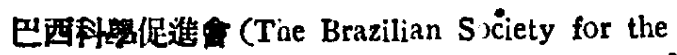
advancement of Science) 已成立，由的洛政授 (Paulo) 担任主席,並出版 Cienciae cultura 嚾誌。

\section{1 第七届國際植物悬合將在瑞典 開金}

第七国国際植物學畜定今年七月十二日，在瑞典京

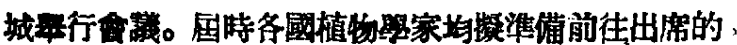

\section{2 柏林工科大悬等近况}

柏林察爾羅頓显温 (Charlottenberg) 的工業專校 (Technische Hochschule)，今已改名爲工科大㫷( Te-

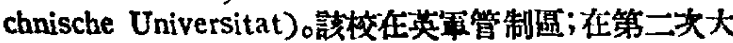

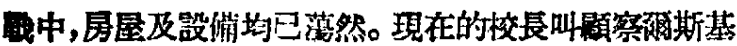
博士 (Kucharski)，是由英軍常局任命的。全校有二O 九六调學生，其中女生二四六人，並且內有一九一人非 德國籍。全校系科包括純科學及礁用科照，以建筑系最

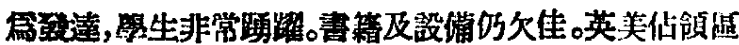
的物理學刊物叫 Zlitschrift fur physik，已於一九四七 年復刊, 由 Von Laue 数授主編。海里滋波動研究所 (Heinrich Hertz Institut fur Schwingungsforschung), 是一個與工科大學合作的研究所，所長李泰寒爾 数授 (Lethauser)，就兼任該校校務委員，現從事然縛電方 面的研究，惟業雅賏受英軍當局的特制。工大另有二物

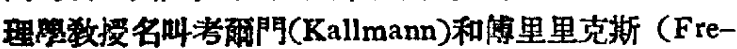
richs),在前威度皇家科學院主持小組的研究; 該處在奏

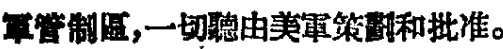

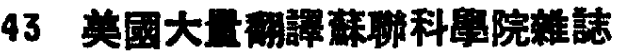

美國原子能委員會在鳥普頓 (Upton) 的布薢克海

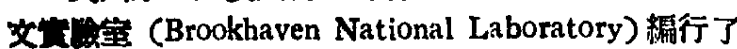

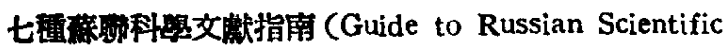
Periodical Literature)。最近又大梘模的期譯蘇愤科學

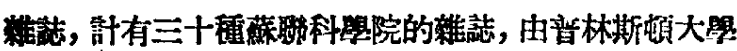

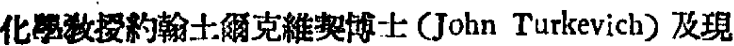
代酛敏授陸第美拉・土爾克維契博士 (Ludmila Turkevich) 二人主持。因自一九四七年以後，蘚聯的科學猚

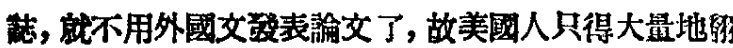

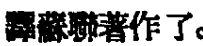

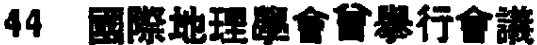

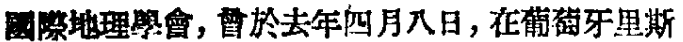

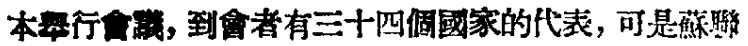
前未派代表去出席。下屇會期䉆一九五二年, 地點化美 圆。

\section{5 美国西拉卡斯大留磁究所反對 美帝戰等尌新}

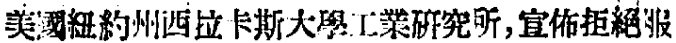

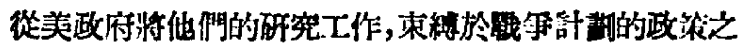

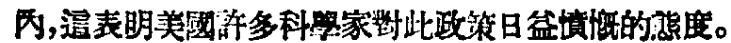

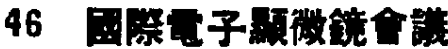

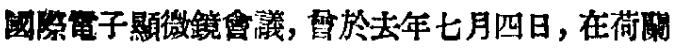

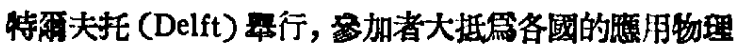
基家以及徽生物盟家。

\section{7 荷藏出版國際性的㴔用科研 究雜誌}

圆際性的新的應用科學猚落 (Applied Scientific

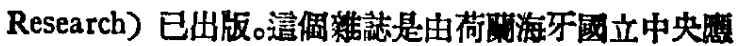

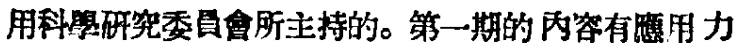

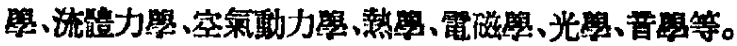

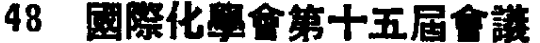

國際化悬會冒於去年九月六日起,在荷首都亞姆 斯特丹䁷行第十五国會蟻，一共開了五天。

\section{9 圆際科嶨文磁會議}

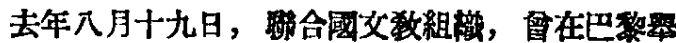

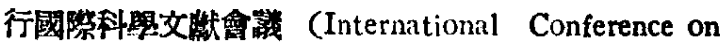
Science Abstracting) 绎諭如何推非备國科照研究報告 的解譯和摘銚的.工作。

\section{0 丹艾出版植物生理學雜誌}

丹麥哥本哈根, 最近出版了一種新型的而內谷豐富 的植物生理照榷誌(Physiologia Plantarium), 用英、德、 生、丹等四國交字發表論交。

\section{1 在甸牙利藇行地贾學第四粑研 究合境}

去年八月廿二日起, 在匈牙利布達佩斯, 曾舆行第 四国國際第四紀研究曾藏(International Conference of the International Association of Quaterary Research),

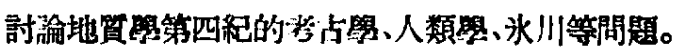

\section{2 英國微生學學會開討論会}

英國徽生學愈 (The Suciety for General Microbislogy）曾於去年四月十八日起, 舉行討論會, 出席者 存英國弗列明敉授 (Fleming 發明配尼唒林者) 以及丹

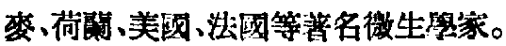

\section{3 法國鞄特数授研究微生物弡明 新的觀察方法}

沠國里界生物化學組織學形究所㑷特致授 (Baud)

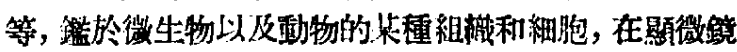

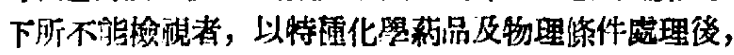

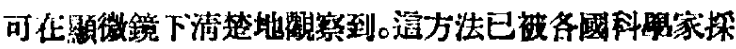
用。 


\section{4 第九屆國绦心理學會䛨}

去年九月十二日起, 在瑞士伯爾尼 (Berne) 曾舉行

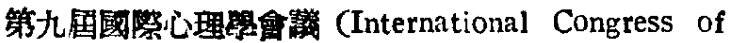
Psychotechnology)，由比隆数授（Piéron）担任主管， 共開了五天。

\section{5 第二尼圆然生物統計學會議}

去年入月三十日起, 在瑞上日內瓦, 曾舉行第二屆

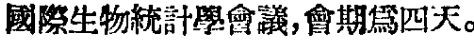

\section{6 國際富驗形態學討論會}

告年七月四日至十二日，在法國斯特拉斯堡(Stras-

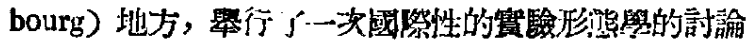
(International Symposium on Morphogenesis)。 通個會是法國國 $\mathrm{i}$ 科學研究中心所召集的,由法网生物

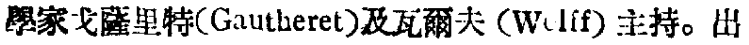

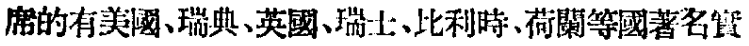
䠯生物學家。

\section{7 第五届國際微生物學會議}

第五国國際微生物學會㼁(International Congress of Microbiology) 預定今年八月十七日至二十四日, 在 巴西首都里咸·底·熱內盧(Rio de Janeiro)舉行, 內签

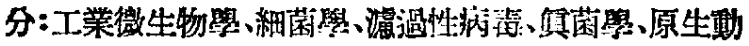
物學、何僂病、植物病理學、土壤微生物學、水童徽生物
䐯、兔疫等。

\section{8 蕉維埃大百科全}

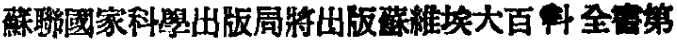

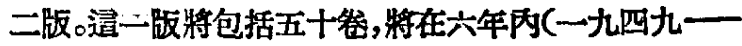

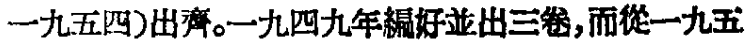
○年起每年将出十焦。

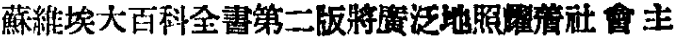

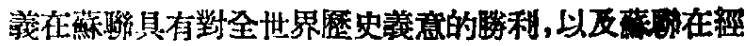

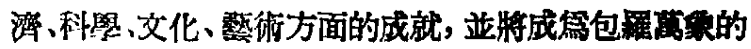
诺裙。

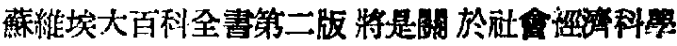
與自然科學、技術、漸事等知識的有录綂的法典。

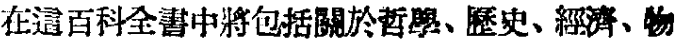

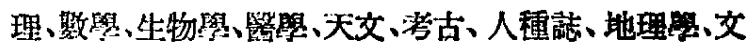

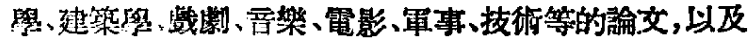

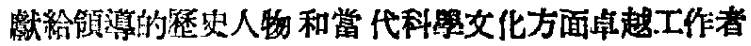
的文章。

在參加編築淄百科全書方面，吸收丁巨大的社會的 政治的㠘科學的力量:院士們,科学院的通訮研究員們，

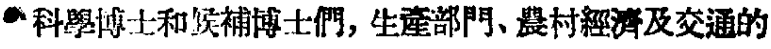
領薄工作者們，作家們，和新聞記者們。

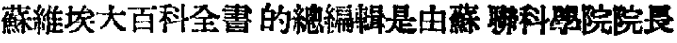
瓦䊒洛头所領漞的。

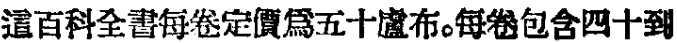

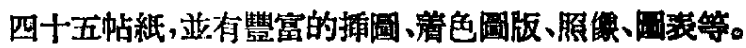

\section{關於本院所收到的一些不能 \\ 成立的 L發明與發現 7 之介紹}

自本院成立五個月以來,曾先後收到不少國內备地

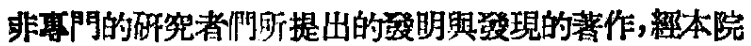

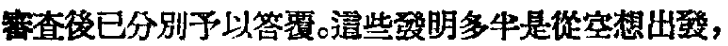
末曾結合諠際, 因们徒耗䩀了許多特間和精力, 而不能

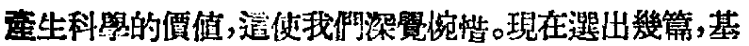
本上有錯誤因而不涽成立的發明潞發現來，介稆於後：

\section{研究原子武器分化計劃}

国偑計部意見書的作者自称：【究研分化原子熱能

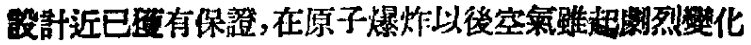

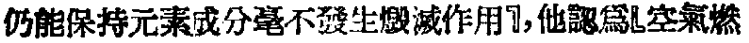

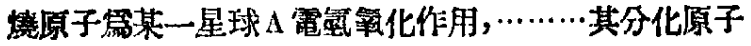

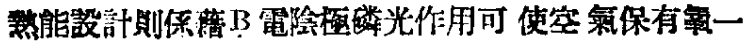

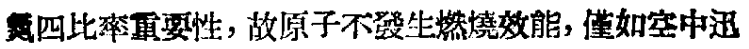

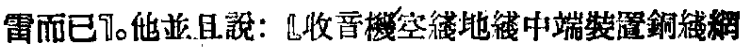

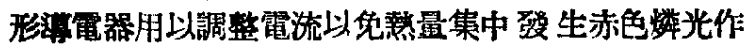

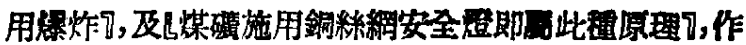
篇他的設計成功之菑澄。

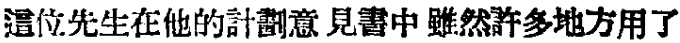

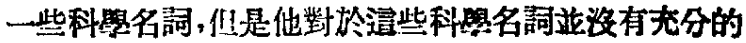

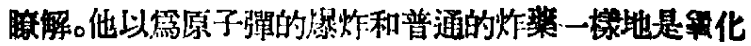

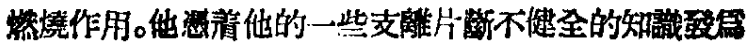
空幻臆想，而缺之科學上的根㨿。

\section{星球起源之新䂰究 \\ 一一天交物理學論文}

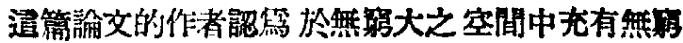

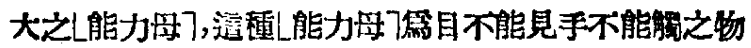

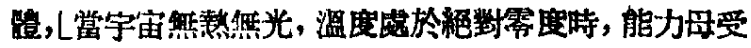
塞力凝聚之作用起狧 烈之反動, 猝 然燃發大量陰陽電

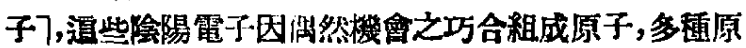

